\title{
On Farm Reproductive Performance and Trait Preferences of Sheep and Goat in Pastoral and Agro-Pastoral Areas of Afar Regional State, Ethiopia
}

\author{
Amare BK*, Abrha HB, Birhane H, and Shishay GE \\ Department of Animal Sciences, Samara University, Afar, Ethiopia
}

*Corresponding author: Amare BK, Department of Animal Sciences, Samara University, Afar, Ethiopia, Fax: +2513-36-66-06-21; Tel: +251920-77-43-09; E-mail: kidaneamare@su.edu.et

Received: 12 Nov, 2020 | Accepted: 25 Jan, 2021 | Published: 02 Feb, 2021

Citation: Amare BK, Abrha HB, Birhane H, Shishay GE (2021) On Farm Reproductive Performance and Trait Preferences of Sheep and Goat in Pastoral and Agro-Pastoral Areas of Afar Regional State, Ethiopia. J Anim Sci Res 5(1): dx.doi.org/10.16966/2576-6457.149

Copyright: (C) 2021 Amare BK, et al. This is an open-access article distributed under the terms of the Creative Commons Attribution License, which permits unrestricted use, distribution, and reproduction in any medium, provided the original author and source are credited.

\begin{abstract}
This study was conducted from March 2018 to January 2019 with the aim of assessing the reproductive performance and traits preferences of sheep and goats producers in pastoral and agro-pastoral area of Afar, Ethiopia. Semi-structured questionnaires and field observations were used to collect the required information from 136 from pastoral and 56 from agro-pastoral. Sheep and goats were kept for a variety of reasons including income generation, insurance (sale for cash to meet unexpected expenditures) and economic security (sale for cash to support foreseeable expenses), social/religious functions and prestige in ownership. In both production systems, next to camels, goats and sheep were ranked as the second and third most important livestock species in accordance to their relative importance. In the current study, there was a significance differences $(P<0.05)$ in the reproductive performance of both sheep and goats between pastoral and agro-pastoral areas. Goats in agro-pastoral areas had noticeably higher average age at first kidding (12.33 \pm 0.76 months), and kidding interval ( $8.76 \pm 2.04$ months) whereas they had lower age at first mating both for Doe and bucks (9.28 \pm 1.85 and $7.98 \pm 2.08$ months, respectively). Similarly, sheep in the agro-pastoral areas had higher age at first lambing $(12.30 \pm 1.18$ months) and lambing interval $(9.16 \pm 2.66$ months) than sheep found in the pastoral areas. In both production systems twinning ability (0.46), fast growth (0.41) and trekking long distances were the main preferred sheep traits, whereas fast growth, milk yield and twining ability were the main goat preferred traits with an overall index value of $0.37,0.32$, and 0.32 , respectively. Genetic improvement programs targeting pastoral and agro-pastoral production system need to be incorporated the traits of preference, multipurpose roles and the existing traditional herding and breeding practices.
\end{abstract}

Keywords: Agro-Pastoral; Afar goat and sheep; Trait preferences

\section{Introduction}

Population growth, urbanization, and income rise in developing countries are the main driver of the increased demand for livestock products [1]. Sheep and goats are an integral part of economic and social life in developing countries. In Ethiopia, sheep and goats are mostly kept by smallholders and the rural poor, including women headed households. Currently the estimated sheep and goat populations are approximately 31.3 million sheep, 32.7 million goats, respectively [2]. These species contribute substantially to the livelihoods of smallholder households as a source of income, food and raw materials (wool, skins). They also serve as a means of risk mitigation during crop failures, savings and investments in addition to other socio-economic and cultural functions. Based on 2017/18 data, the livestock sector contributes up to $25.6 \%$ of agricultural GDP and $10.5 \%$ of total Ethiopian foreign exchange earnings [3]. The high stock numbers, however, are not leading to higher exports or export earnings for live animals or meat. Ethiopia's annual exports of cattle and sheep meat were valued at USD 79.13 million in 2012 The lower export level in Ethiopia could possibly be attributed to stronger local demand leading to higher prices, relatively lower meat output and differences in efficiency of meat production systems [4]. Thus, small ruminant meat production was expected to grow annually by $4 \%$ on average for the 2012-2016 periods, reaching 61,000 tons in 2016 because of strong demand for goat meat in the domestic and export markets [5]. The small ruminant industry in Ethiopia contributes substantially to the livelihood of the rural poor and the country at large but is faced with various challenges.

Despite huge and genetically diverse goat and sheep population in Ethiopia, productivity per animal and flock off-take are low which the average annual estimates off-take rate from sheep and goat flocks for the years 2008-2010 was between 30\% and 38\% [5]. One major shortfall has been weak planning, particularly poor involvement of livestock owners and stakeholders in the design and implementation of the programs. Furthermore, high density of animals in relation to grazing capacity, unreliable and erratic rainfall, increasing human population, small landholding, and declining land productivity are all major concerns. Therefore, the ultimate objective of the study was to identify trait preferences and reproductive performance of sheep and goats in selected areas of afar regional state Ethiopia. 


\section{Material and Methods}

\section{Description of study area}

The study was conducted in four districts of Afar national regional state of Ethiopia (Figure 1). Afar regional state is located in the north eastern part of the country $588 \mathrm{kms}$ far from the capital city. Geographically it is located between $39^{\circ} 34^{\prime}$ and $42^{\circ} 28^{\prime}$ East Longitude and $8^{\circ} 49^{\prime}$ and $14^{\circ} 30^{\prime}$ North Latitude [6]. The region borders four national regional states i.e., in the North and Northwest, Tigray region; in West and Southwest, Amhara region; in South, Oromia region and in South West, Somalia region. It also shares international borders with Djibouti and Eritrea to the West and North West, respectively. There are four distinct seasons in the region, namely, Karima (summer), Hagay (autumn), Gilal (winter) and Sugum (spring). It is characterized by an arid and semi-arid climate with low and erratic rainfall. The annual temperature and rainfall in the region is $30-50^{\circ} \mathrm{C}$ and $200-600 \mathrm{~mm}$, respectively. The altitude in the region ranges from 100-1000 meters above sea level [7]. The total population of the region is estimated at 1.2 million of which $90 \%$ are pastoralists and agro-pastoralism (10\%) is now emerging following some permanent and temporary rivers on which small scale irrigation is developed. Animal husbandry in Afar region is characterized by extensive pastoral production system and seasonal mobility. The Afar region is endowed with livestock resource comprising of 2,336,488 heads of cattle, 4,267,969 head of goats, 2,463,632 head of sheep, 852,016 head of camels and 187,287 head of equines that support the region and contribute to the national economy.

\section{Population and sample}

The study was conducted from March 2018 to January 2019. For the study, a total of 192 sheep and goat households were surveyed across the study sites to explore general information about traits preferences, reproductive performance, breeding practices, indigenous knowledge of pastoralists and agro-pastoralists. Before the actual work was started, focused group discussions were held with the different experts working, at the regional and zonal agricultural development office. Furthermore, four open group discussions (4-9 members) were carried out at the selected sites of each district to fill any emerging information gap. A total of 384 sheep and goats were sampled purposely from each districts (ninety six from each district). Information on household family size, type of livestock reared by the community, major routine animal husbandry practices were recorded using a pretested semistructured questionnaire.

\section{Statistical analyses}

The Statistical Package for Social Sciences program was used to describe the survey data [8]. Chi-square test was employed when required to test the independence of categories or to assess the statistical significance. Indexes were calculated for ranking data from individual households for site according to a formula: Index=sum of ( 3 for rank $1+2$ for rank $2+1$ for rank 3 ) given for an individual reason (attribute) divided by the sum of ( 3 for rank $1+2$ for rank $2+1$ for rank 3 ) for overall reasons. Indexes so generated were then used to rank the pooled importance of each attribute as selection criteria in each of the three sites.

\section{Results}

\section{Educational background of the respondents}

The level of education in study area is presented in figure 2. Out of the interviewed, $69.2 \%$ of the respondents were illiterate which had no educational status whereas, the remaining $30.8 \%$ proportion of the respondents were relatively accustomed with writing and reading. Considering literate who attended schooling, proportionally a higher percentage (19.2 \%) attended grade 1-3 followed by $(8.3 \%)$ attended grade $4-6$ and $(3.3 \%)$ were attended above grade six.

\section{Purpose of keeping sheep and goats}

The reasons for keeping sheep and goat are reasonable and are related to the pastoralists needs in the long or short term. The ranking

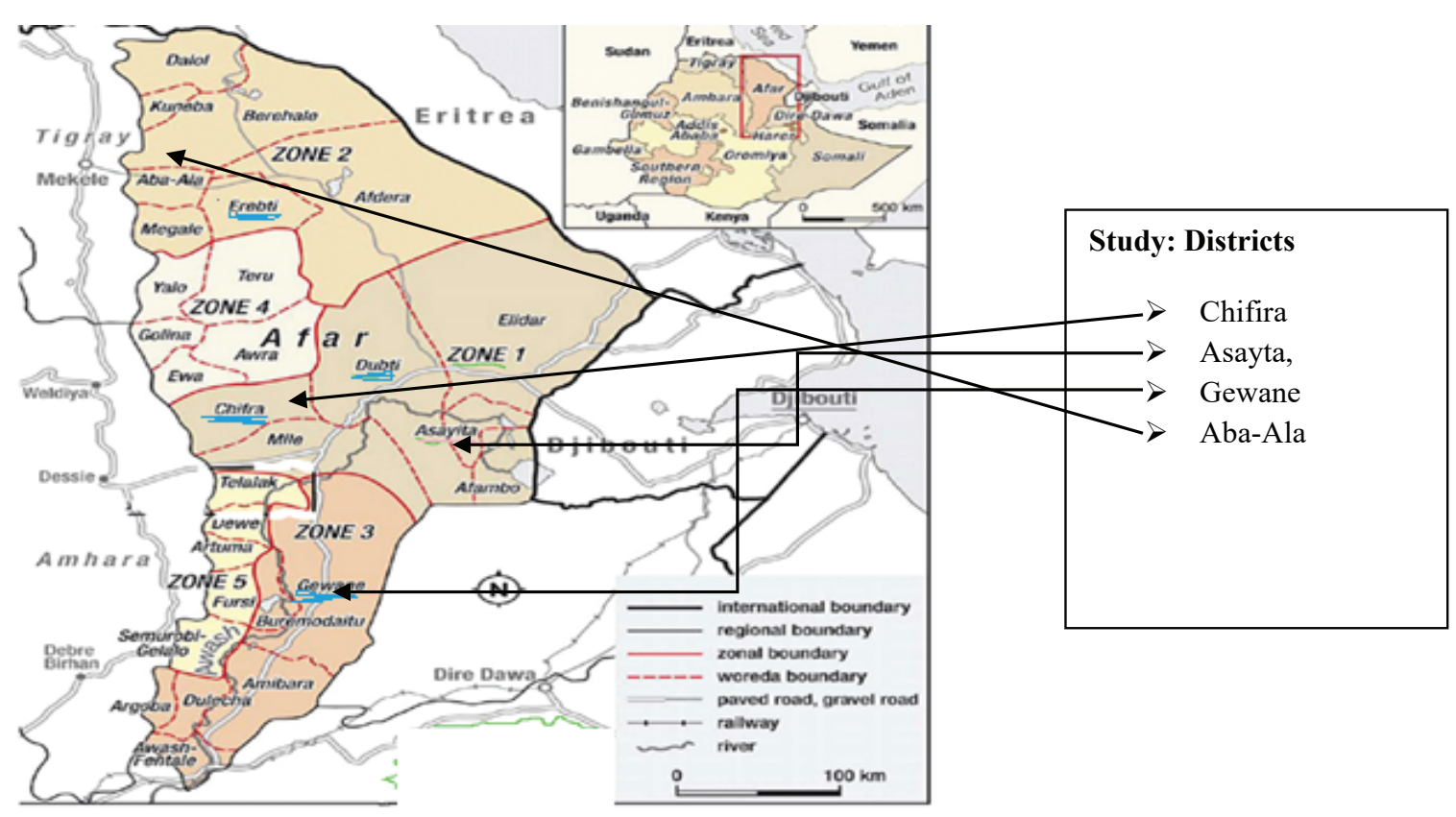

Figure 1: Administrative location of Afar region showing the study zones and Districts. 


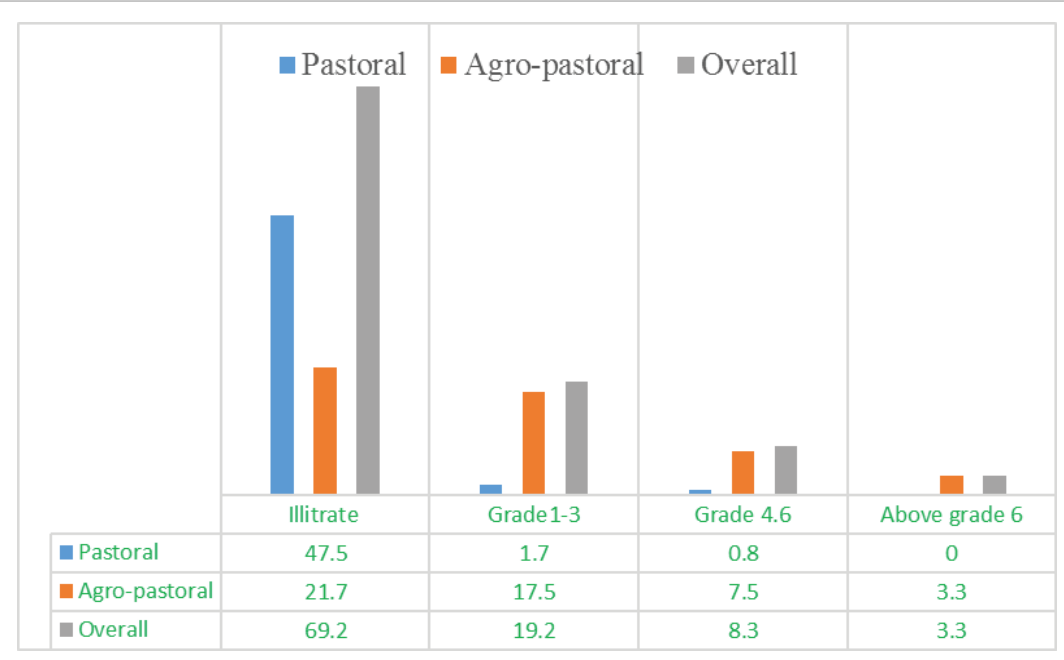

Figure 2: Educational status of respondents.

of respondent for sheep and goat are presented in table 1 . The results revealed that, sheep and goat were kept for the purpose of cash, home consumption and for the purpose of saving with an overall index value of $0.42,0.395$ and 0.16 , respectively. However, some respondents were also kept sheep and goat as indication of wealth status (0.05) particularly in the pastoral area of the study sites. During group discussions, the community members strongly stressed on sheep and goats which can be easily sold in the nearby markets whenever there is an urgent need for cash; hence they were protected camel and cattle from being sold for minor problems.

\section{Livestock preference}

Ranking of livestock species preference in both pastoral and agropastoral areas of Afar are presented in table 2. Accordingly, camel was ranked as the first most preferred livestock species in both production systems followed by goats and sheep as the second and third preferred livestock species. Whereas, cattle were the fourth-less preferred livestock species in the overall study. This was due to the ability of camels and goats to survive and perform under harsh environmental conditions.

\section{Reproductive performance of sheep and goat}

Age at first kidding/lambing: The age at first kidding was influenced by genetic makeup and environmental factors that determine the total production of goats in their life span. The age at first kidding and lambing in the study area are present in tables 3 and 4 . In the pastoral area the mean age at first kidding was $12.22 \pm 0.66$, whereas in the agro-pastoral areas the mean age at first kidding was $12.33 \pm$ 0.75 months, respectively with an overall mean value of $12.28 \pm 0.70$ months. Similarly, age at first lambing was significant $(\mathrm{P}<0.05)$ among the pastoral and agro-pastoral production systems. In the pastoral areas the mean age at first lambing was $11.75 \pm 1.57$ months, whereas in the agro-pastoral areas the mean $12.30 \pm 1.82$ months which was higher than that of pastoral areas, respectively.

Age at first mating for ewe and doe: According to the study report, in the pastoral areas the mean age at first mating was $9.40 \pm 1.45$ and $8.28 \pm 1.98$ months for female and male goats, respectively, whereas in the agro-pastoral areas, the age at first mating was $9.28 \pm 1.85$ and $7.98 \pm 2.08$ months for female and male goats, respectively table 3 . Similarly, age at first mating for sheep was significant $(\mathrm{P}<0.05)$ among pastoral and agro-pastoral productions of the afar region. In the pastoral areas the age at first mating was $8.71 \pm 1.88$ and $8.28 \pm 1.98$ months for female and male sheep, respectively, whereas in the agropastoral areas $9.53 \pm 1.82$ and $7.93 \pm 2.08$ months for female and male sheep was obtained, respectively.

Kidding/lambing interval: Kidding and lambing interval was significant $(\mathrm{P}<0.05)$ among pastoral and agro-pastoral production systems both for sheep and goats. In the pastoral areas the kidding and lambing interval was $7.66 \pm 2.48$ and $8.02 \pm 2.39$ months for goats and sheep, respectively. Similarly, in the agro-pastoral areas the kidding and lambing interval was $8.76 \pm 2.04$ and $9.16 \pm 2.66$ months for goats and sheep, respectively.

Parity of sheep and goats: Based on the information obtained from the community members, maximum parity of does and ewes were recorded in pastoral areas of Afar region. Parity was significant $(\mathrm{P}<0.05)$ between production both for sheep and goats. In the pastoral areas, it was found $4.40 \pm 1.18$ and $3.29 \pm 1.18$ numbers for sheep and goats, respectively. Similarly, $4.00 \pm 0.76$ and $3.00 \pm 0.76$ parity numbers was obtained for both sheep and goats in the agro-pastoral areas of afar region, respectively.

\section{Trait preferences of sheep and goat in pastoral and agro- pastoral areas}

On-farm pastoral and agro-pastoral sheep and goat producers comprised their own traits of preferences and production objectives. In the current study, respondents were listed their concerned type of traits and then each traits were ranked accordingly. The results obtained on the trait preference from own flock ranking both for sheep and goat are presented in tables 5 and 6 , respectively. Results of the study indicated that, twining ability $(0.60)$, fast growth $(0.48)$ and trekking long distance (0.21) were the most highly rated traits for selecting sheep in the pastoral production system, respectively. On the other hand, fast growth, twinging ability and disease resistance were the main preferred traits for selection sheep in the agropastoral production system with an index value of $0.34,0.32$, and 0.13 , respectively. Similarly, the traits preferences for goats in both pastoral and agro-pastoral are presented in table 6 . In the pastoral goat production systems, fast growth, twining ability and milk yield were the three most preferred traits with an index value of $0.45,0.42$, and 
Table 1: Ranking of socio-economic importance of sheep and goats in both pastoral and agro-pastoral areas of Afar.

\begin{tabular}{|c|c|c|c|c|c|c|c|c|c|}
\hline \multirow{3}{*}{ Traits } & \multicolumn{9}{|c|}{ Production system } \\
\hline & \multicolumn{4}{|c|}{ Pastoral } & \multicolumn{5}{|c|}{ Agro-pastoral } \\
\hline & Rank 1 & Rank 2 & Rank 3 & Index & Rank 1 & Rank 2 & Rank 3 & Index & Overall \\
\hline Cash & $42.2(81)$ & $20.8(40)$ & $7.8(15)$ & 0.41 & $16.7(32)$ & $12.5(24)$ & 0.0 & 0.43 & 0.42 \\
\hline Save & 0.0 & $12.0(23)$ & $38.0(73)$ & 0.15 & 0.0 & 0.0 & $29.2(56)$ & 0.17 & 0.16 \\
\hline Consumption & $28.6(55)$ & $38.0(73)$ & $4.2(8)$ & 0.39 & $12.5(24)$ & $16.7(32)$ & 0.0 & 0.40 & 0.395 \\
\hline Wealth & 0.0 & 0.0 & $20.8(40)$ & 0.05 & 0.0 & 0.0 & 0.0 & 0.00 & 0.025 \\
\hline
\end{tabular}

Table 2: Household's ranking of livestock species preference in both pastoral and agro-pastoral areas of Afar.

\begin{tabular}{|l|c|c|c|c|c|}
\hline \multirow{2}{*}{$\begin{array}{c}\text { Livestock } \\
\text { species }\end{array}$} & \multicolumn{5}{|c|}{ Production systems } \\
\cline { 2 - 6 } & $\begin{array}{c}\text { Pastoral } \\
\mathbf{N = 1 3 6}\end{array}$ & $\begin{array}{c}\text { Agro-pastoral } \\
\mathbf{N = 5 6}\end{array}$ & Weight & Index & Rank \\
\hline Camel & 136 & 56 & 428 & 0.34 & 1 \\
\hline Cattle & 136 & 56 & 149.8 & 0.12 & 4 \\
\hline Sheep & 136 & 56 & 208.3 & 0.16 & 3 \\
\hline Goat & 136 & 56 & 316.7 & 0.25 & 2 \\
\hline
\end{tabular}

$\mathrm{N}=$ Number of respondents; Rank 1=Most important; Rank 4=Less important

Table 3: Reported reproductive performances of goats for both pastoral and agro pastoral areas of Afar.

\begin{tabular}{|l|c|c|c|c|}
\hline \multirow{2}{*}{\begin{tabular}{c}
\multirow{2}{*}{$\begin{array}{c}\text { Reproductive } \\
\text { parameter }\end{array}$} \\
\cline { 2 - 5 }
\end{tabular}} & \multicolumn{3}{|c|}{ Production system classification in mean standard } \\
deviation
\end{tabular}

Table 4: Reported reproductive performances of sheep both for pastoral and agro pastoral areas of Afar.

\begin{tabular}{|l|c|c|c|}
\hline \multirow{2}{*}{ Reproductive parameter } & \multicolumn{3}{|c|}{$\begin{array}{c}\text { Production system classification in mean } \\
\text { standard deviation }\end{array}$} \\
\cline { 2 - 4 } & Pastoral & Agro-pastoral & Mean( \pm SD) \\
\hline $\begin{array}{l}\text { Age at first lambing } \\
\text { (month) }\end{array}$ & $11.75 \pm 1.57^{\mathrm{a}}$ & $12.30 \pm 1.18^{\mathrm{b}}$ & $12.08 \pm 1.38$ \\
\hline Lambing interval (month) & $8.02 \pm 2.39^{\mathrm{a}}$ & $9.16 \pm 2.66^{\mathrm{b}}$ & $8.59 \pm 2.53$ \\
\hline Service period (month) & $1.47 \pm 0.60^{\mathrm{b}}$ & $1.28 \pm 0.45^{\mathrm{a}}$ & $1.38 \pm 0.53$ \\
\hline Parity (No) & $4.40 \pm 1.18^{\mathrm{b}}$ & $4.00 \pm 0.76^{\mathrm{a}}$ & $4.20 \pm 0.97$ \\
\hline $\begin{array}{l}\text { Age at first mating ewe } \\
\text { (month) }\end{array}$ & $8.71 \pm 1.88^{\mathrm{a}}$ & $9.53 \pm 1.82^{\mathrm{b}}$ & $9.12 \pm 1.89$ \\
\hline $\begin{array}{l}\text { Age at first mating of rams } \\
\text { (month) }\end{array}$ & $8.28 \pm 1.98^{\mathrm{b}}$ & $7.93 \pm 2.08^{\mathrm{a}}$ & $8.10 \pm 2.03$ \\
\hline
\end{tabular}

0.34 , respectively. Unlike to the pastoral goat production systems, milk yield (0.29), fast growth (0.29) and twining ability (0.21), respectively were the most highly rated goat traits in the agro-pastoral production systems.

\section{Constraints of sheep and goats production}

Production constraints, which were defined by sheep and goats owners in both areas, are presented in figure 3 . Feed shortage (0.33), Disease (0.27), water shortage (0.25) and drought (0.15) were the most pertinent production constraints in the agro-pastoral areas, whereas in the pastoral areas, disease, feed shortage, water and drought were the main production constraints with an index value of $0.40,0.32,0.20$, and 0.08 , respectively.

\section{Discussion and Conclusion}

For sustainable genetic improvement programs understanding the existing reproductive performance, community traits preferences and the relative importance of different production constraints is an indispensable task [9]. The role of education is obvious in affecting household income, adopting technologies, demography, health, and as a whole the socio-economic status of the family and the county as well [10]. In the present study sites, $69.2 \%$ of the respondents were illiterate which had no educational status whereas, the remaining $30.8 \%$ proportion of the respondents were relatively accustomed with writing and reading. Unlike to the present study, majority of (84.1\%) the household heads in the rural agro-pastoral areas of Uganda had attained formal education [11]. Considering literate who attended schooling, proportionally a higher percentage (19.2\%) attended grade 1-3 followed by ( $8.3 \%)$ attended grade $4-6$ and $(3.3 \%)$ were attended above grade six. Inline to the present study, higher proportion of illiterate $(79.4 \%)$ and lower level of primary $(2.4 \%)$ were reported in Jeldessa, Mudianeno [12]. Therefore, this finding clearly reflects the nearby community in the previous period was unable to find the access of learning due to the severe scarcity of infrastructures and lack of awareness about schooling but yet the target people even from remote areas are highly salivate schooling although the access of infrastructure is also diversified in all over the region.

The reasons for keeping sheep and goat are reasonable and are related to the pastoralists needs in the long or short term. The results revealed that, sheep and goat were kept for the purpose of cash, home consumption and for the purpose of saving with an overall index value of $0.42,0.395$ and 0.16 , respectively. The purpose of keeping sheep and goat in the present study was similar to the report that cash was the main purpose of keeping goats in the rural agro-pastoral areas of Uganda [13]. However, it was not consistent with the report of sheep and goats in the different agro-ecologies of central Java, Indonesia [14]. During group discussions, the community members strongly stressed on sheep and goats which can be easily sold in the nearby markets whenever there is an urgent need for cash; hence they were protected camel and cattle from being sold for minor problems. These reasons 


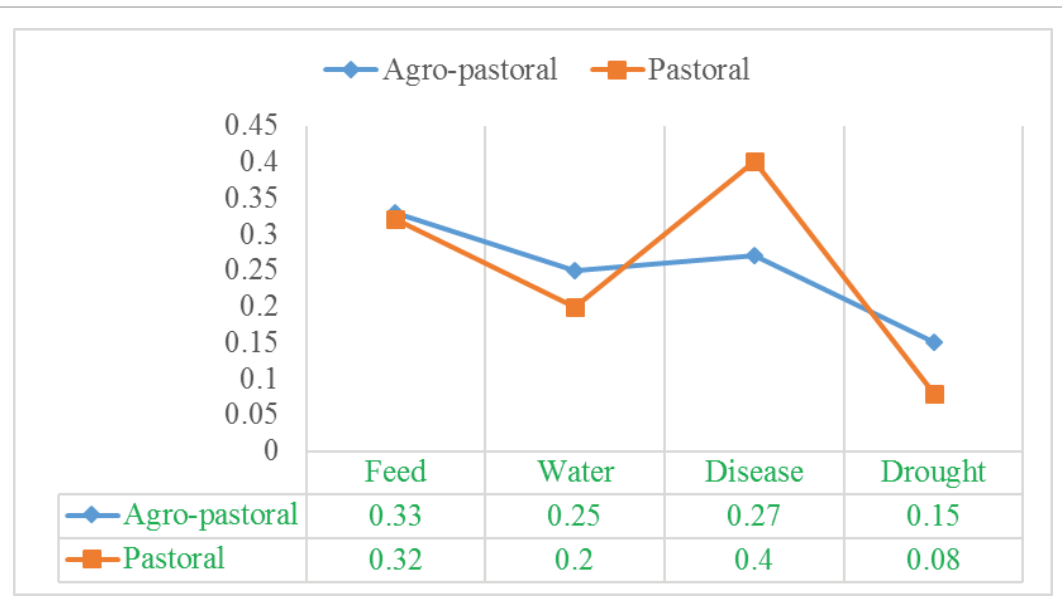

Figure 3: Constraints of sheep production.

Table 5: Ranking of respondents on sheep traits preferences.

\begin{tabular}{|l|c|c|c|c|c|c|c|c|c|}
\hline \multirow{2}{*}{ Traits } & \multicolumn{4}{|c|}{ Pastoral (N=136) } & \multicolumn{4}{c|}{ Agro- pastoral (N=56) } \\
\cline { 2 - 11 } & Rank 1 & Rank 2 & Rank 3 & Index & Rank 1 & Rank 2 & Rank 3 & Index & Overall Index \\
\hline Milk yield & $5.2(7)$ & $4.4(6)$ & $2.2(3)$ & 0.07 & $5.1(7)$ & $4.4(6)$ & $1.5(2)$ & 0.10 & 0.085 \\
\hline DR & $2.2(3)$ & $9.6(13)$ & $31.6(43)$ & 0.14 & $1.5(2)$ & $5.1(7)$ & $17.6(24)$ & 0.13 & 0.135 \\
\hline TLD & $1.5(2)$ & $19.9(27)$ & $40.4(55)$ & 0.21 & $1.5(2)$ & $5.1(7)$ & $10.3(14)$ & 0.10 & 0.155 \\
\hline TWA & $61.8(84)$ & $25.7(35)$ & $2.9(4)$ & 0.60 & $19.1(26)$ & $9.6(13)$ & $2.9(4)$ & 0.32 & 0.46 \\
\hline FG & $29.4(40)$ & $39.7(54)$ & $24.3(33)$ & 0.48 & $14.0(19)$ & $16.9(23)$ & $8.8(12)$ & 0.34 & 0.41 \\
\hline
\end{tabular}

$\mathrm{N}=$ Number of respondents; DR=Disease Resistance; TLD=Trekking Long Distances; TWA=Twining Ability; FG=Fast Growth

Table 6: Ranking of respondents on goat traits preferences.

\begin{tabular}{|c|c|c|c|c|c|c|c|c|c|}
\hline \multirow{2}{*}{ Traits } & \multicolumn{4}{|c|}{ Pastoral (N=136) } & \multicolumn{5}{c|}{ Agro-pastoral (N=56) } \\
\cline { 2 - 11 } & Rank 1 & Rank 2 & Rank 3 & Index & Rank 1 & Rank 2 & Rank 3 & Index & Overall Index \\
\hline Milk & $28.7(39)$ & $17.6(24)$ & $14.0(19)$ & 0.34 & $16.2(22)$ & $10.3(14)$ & $2.2(3)$ & 0.29 & 0.315 \\
\hline DR & $2.2(3)$ & $8.8(12)$ & $37.5(51)$ & 0.15 & $1.5(2)$ & $4.4(6)$ & $17.6(24)$ & 0.13 & 0.14 \\
\hline TLD & $1.5(2)$ & $14.0(19)$ & $21.3(29)$ & 0.14 & $1.5(2)$ & $4.4(6)$ & $8.8(12)$ & 0.09 & 0.115 \\
\hline TWA & $41.2(56)$ & $21.3(29)$ & $2.9(4)$ & 0.42 & $11.0(15)$ & $7.4(10)$ & $2.9(4)$ & 0.21 & 0.315 \\
\hline FG & $26.5(36)$ & $37.5(51)$ & $25.0(34)$ & 0.45 & $11.0(15)$ & $14.7(20)$ & $9.6(13)$ & 0.29 & 0.37 \\
\hline
\end{tabular}

$\mathrm{N}=$ Number of Respondents; DR=Disease Resistance; TLD=Trekking Long Distances; TWA=Twining Ability; FG=Fast Growth

were similar with the results from the traditional small stock farmer's survey in Botswana, who indicated that, most farmers sold their goats because of urgent cash needs [15]. The present findings on the other hand, was different from the results of a study on rural community farming system in South Africa who reported that meat consumption was the major reasons for keeping goats [16]. Accordingly, camel was ranked as the first most preferred livestock species in both production systems followed by goats and sheep as the second and third preferred livestock species. Whereas, cattle were the fourth-less preferred livestock species in the overall study. This was due to the ability of camels and goats to survive and perform under harsh environmental conditions. Unlike to the present study, in the lowlands of western Tigray, Ethiopia, sheep were the first preferred livestock species [17]. Whereas, in the mixed farming system of the highlands and mid-altitudes of Ethiopia where crop production is important; cattle were the most important livestock species for cultivation, threshing, manure and milk [18]. In the lowlands where crop production is not reliable, camels and goats production has experienced success [19]. The abundance of browse plants could favor camel and goat keeping in the lowland than in the highland and midland agro-ecological zones and could be the major reason for why camel and goats ranked first and second in the selected study sites.

Puberty is the period on which animals show marked signs and symptoms of sexual maturity whereas age at first mating is the exact time on which animals show full maturity and start to produce egg and ejaculate sperm cell. According to the study report, in the pastoral areas the mean age at first mating was $9.40 \pm 1.45$ and $8.28 \pm 1.98$ months for female and male goats, respectively, whereas in the agropastoral areas, the age at first mating was $9.28 \pm 1.85$ and $7.98 \pm 2.08$ months for female and male goats, respectively. The overall mean age at first mating obtained in the present study was lower than the average 
age at puberty for male $(11.1 \pm 1.5$ months $)$ and female $(12.7 \pm 2.1$ months), respectively [20]. Nevertheless it was higher than age at first mating for Begait male (6 months) and female goats (7 months) [21]. Similarly, age at first mating for sheep was significant $(\mathrm{P}<0.05)$ among pastoral and agro-pastoral productions of the afar region Afar goats and sheep showed delayed age at first mating compared to Red sokoto goats (4-5 months) of Nigeria, and highly delayed than central zone of Tigray ( $8.90 \pm 2.5$ months) goats [22]. Kidding/lambing interval is the interval between two parturitions and it is one of the major components of reproductive performance, which is highly influenced through production systems. Kidding and lambing interval was significant $(\mathrm{P}<0.05)$ among pastoral and agro-pastoral production systems both for sheep and goats. The overall mean kidding interval $(8.21 \pm 2.26$ months) and lambing interval (8.59 \pm 2.53 months) for Afar goat and sheep was highly comparable with the findings conducted on Dale district of Sidama zone that was 8.56 months [23]. However, the present study results were lower than the reported kidding interval for Abergelle and Central Highland goats, which were $11.31 \pm 2.21$ and $10.3 \pm 1.42$ months, respectively [24].

Pastoral and agro-pastoral livestock producers comprised their own traits preferences and production objectives. The present results obtained in the pastoral and agro-pastoral sheep producers were incomparable with Wollo highland sheep who reported that fast growth, body size and weaning rate were the main prioritized traits according to their order of importance [25]. Disparate to the pastoral goat production systems, milk yield (0.29), fast growth (0.29) and twining ability (0.21), respectively were the most highly rated goat traits in the agro-pastoral production systems. Comparing to the pastoral goat production systems, body conformation $(0.25)$, coat color $(0.20)$, twining ability $(0.18)$ and adaptation (0.16), respectively were the most preferred WoytoGuji goat traits in the lowland of Loma districts, Southern Ethiopia [26]. The most pertinent production constraints in ranked in the agro-pastoral areas were feed shortage, Disease, water shortage and drought whereas, in the pastoral areas, disease, feed shortage, water and drought were the main production constraints, respectively. Parallel to the present study, disease, feed shortage and water problems were reported the main Begait sheep production constraints in Wester Tigray, Ethiopia [27].

In conclusion the present study shows that, trait preferences and reproduction performance of sheep and goats reflect the general production environment and market preferences operating in the pastoral and agro-pastoral areas. Pastoralists and agro-pastoralists of Afar goats and sheep producers preferred traits like, fast growth performance, twinning ability, milk yield ability and long distance tracking for searching of their feed. The existing reproductive performance of the afar sheep and goats were low. Hence, to improve the productive performance of the Afar sheep and goats there is a need to alleviate the technical constraints and increase adoption of improved technologies and appropriate delivery of extension messages.

\section{Acknowledgements}

We are grateful to the pastoral and agro-pastoral communities of Chifra, Asayta, Gewane and Aba-Ala for their willingness and as sources of necessary data and information and Samara University for backing this research.

\section{Conflicts of Interest}

The authors declare that there are no conflicts of interest.

\section{References}

1. United Nations, Department of Economic and Social Affairs, Population Division (2017) World Population Prospects: The 2017 Revision, Key Findings and Advance Tables. Working Paper No. ESA/P/WP/248.

2. Central Statistical Authority, Federal Democratic Republic of Ethiopia central statistical agency (2000) Agricultural sample survey: Report on livestock and livestock characteristics (private peasant holdings). Statistical Bulletin, Addis Ababa, Ethiopia 587.

3. National Bank of Ethiopia (2018) Annual report 2017/2018. NBE, Addis Ababa, Ethiopia.

4. Ethiopian Customs and Revenue Authority (2012) Raw data on the type, volume, value and destination of export items from Ethiopia. ECRA, Addis Ababa, Ethiopia.

5. Legese G, Fadiga M (2014) Small ruminant value chain development in Ethiopia: Situation analysis and trends. International Center for Agricultural Research in the Dry Areas/International Livestock Research Institute, ICARDA/ILRI Project Report, Nairobi, Kenya.

6. Federal Democratic Republic of Ethiopia, Population Census Commission (2008) Summary and statistical report of the 2007 Population and Housing Census. United Nations Population Fund, Addis Ababa, Ethiopia.

7. Amsalu A, Adem A (2009) Assessment of climate change-induced hazards, impacts and responses in the southern lowlands of Ethiopia. Cordaid, Forum for Social Studies, Addis Ababa, Ethiopia.

8. SPSS (2007) Software Package for Social Sciences Version 16.0 for Window.

9. Baker RL, Gray GD (2004) Appropriate breeds and breeding schemes for sheep and goats in the tropics: The importance of characterization and utilizing disease resistance adaptation to tropical stress. In: Sani R, Gray GD, Baker RL (eds) Worm control for Small Ruminant in Tropical Asia. Australian Center for international Agricultural Research.

10. Belay D (2008) Growth, reproductive performance and carcass characteristics of abergelle and central Highland goat types under traditional management in sekota woreda. Haramaya University, Ethiopia.

11. Kebede $A B$ (2009) Characterization of milk Production Systems, Marketing and On-Farm Evaluation of the effect of Feed Supplementation Milk yield and Milk Composition of Cows at Bure District, Ethiopia, Bahir Dar University, Ethiopia.

12. Byaruhanga C, Oluka J, Olinga S (2015) Socio-economic Aspects of Goat Production in a Rural Agro-pastoral System of Uganda. Universal J Agri Res 3: 203-210.

13. Gebreyesus G (2010) Community-based participatory characterization of the short eared Somali Goat population around Dire, Ethiopia. Haramaya University, Dire Dawa, Ethiopia.

14. Budisatria IGS (2006) Dynamics of sheep and goat development in Central Java-Indonesia. PhD Thesis, Animal Production Systems Group, Wageningen University.

15. Nsoso SJ, Podisi B, Otsogile E, Mokhutshwane BS, Ahmadu B (2004) Phenotypic characterization of indigenous Tswana goats and sheep breeds in Botswana. Trop Ani Health Prod 36: 789-800.

16. Braker MJE, Udo HMJ, Webb EC (2002) Impact of intervention objectives in goat production within subsistence farming systems in South Africa. South African J Ani Sci 32: 185-191. 
17. Berhe A, Yesihak Yusuf $Y$, Ahmed WH (2019) Breeding Practices, Flock Structure and Reproductive Performance of Begait Sheep in Ethiopia. J Reproduct Infertility 10: 24-39.

18. Asamenew G, Beyene H, Negatu W, Ayele G (1999) A survey of farming systems of vertisol areas of the Ethiopian Highlands. In: Tekalign Mamo, Abiye Astatke, Srivastra KL, Asgelil Dibabe (eds) Improved management of vertisols for sustainable crop-livestock production in the Ethiopian Highlands: Synthesis Report 1986-92. Technical committee of the joint vertisol project, Addis Ababa, Ethiopia 29-49.

19. Tsegahun A, Lemma S, Sebsbie A, Mekoya A, Sileshi Z (2000) National goat research strategy in Ethiopia. In: Merkel RC, Abebe G, Goetsch AL (eds) The Opportunities and Challenges of Enhancing Goat Production in East Africa. Proceedings of a conference held at Debub University, Awassa, Ethiopia from November 10 to 12.

20. Gebreyowhens W, Kumar R (2018) Management and Breeding Objectives of Maefur goat breed type in Erob district eastern Zone of Tigray, Ethiopia. Int J Livestock Product 9: 50-66.

21. Gebrekiros H, Kefelegn K, Banerjee AK, Wolde Z (2016) On-Farm Phenotypic Characterization of Begait Goat and Their Production System in Western Zone of Tigray, Ethiopia. Inter J Res Innovat Earth Sci 3: 2394-1375.
22. Assen Ebrahim, Aklilu Hailemichael (2012) Sheep and goat production and utilization in different agro-ecological zones in Tigray, Ethiopia. Livest Res Rural: 24.

23. Endeshaw A (2007) Assessment on production system and marketing of goats at Dale district (Sidama Zone). MSc Thesis. Hawassa University, Awassa, Ethiopia.

24. Belay Deribe (2018) Growth, reproductive performance and carcass characteristics of abergelle and central Highland goat types under traditional management in sekota woreda. MSc thesis presented at Haramaya University.

25. Amare Tadesse, Gebeyehu Goshu, Berhan Tamir (2018) Flock composition, breeding strategies and farmers' traits of interest evaluation of Wollo highland sheep and their $F_{1}$ crosses. J Anim Sci Technol 60: 14 .

26. Yaekob Lorato, Kirman Manzoor Ahmed, Birhanu Belay (2015) Participatory identification of breeding objective traits of WoytoGuji goat in Loma district, Southern Ethiopia. Int J Livest Prod 8: 131-135.

27. Amare B, Kefyalew A, Mekuria Z (2012) Typical features, characterization and breeding objectives of Begait sheep in Ethiopia. Food and Agriculture Organization of the United Nations, Animal Genetic Resources 51: 117-123. 